\title{
Biomonitoring the Vitex gardneriana Shauer (Lamiaceae) Toxic Effects to Shed Light on Bioactive Compounds against a Major Coconut Pest Mite
}

\author{
Anderson Soares de Almeida ${ }^{1}$, Caroline Rabelo Coelho ${ }^{2}$, Mirele Santana de Sá ${ }^{3}$, \\ Edson de Souza Bento ${ }^{4}$, Alberto Wisniewski Junior ${ }^{3}$, Adenir Vieira Teodoro ${ }^{5}$, \\ Haroudo Sátiro Xavier ${ }^{6}$, Jose Guedes de Sena Filho ${ }^{{ }^{*}}$

\footnotetext{
${ }^{1}$ Departamento de Farmácia, Universidade Federal de Sergipe, Cidade Universitária Professor José Aloísio de Campos, Avenida Marechal Rondon s/n, Bairro Jardim Rosa Elze, São Cristóvão, Brazil

${ }^{2}$ Universidade Estadual do Maranhão, Cidade Universitária Paulo VI s/n, Bairro Tirirical, São Luís, Brazil

${ }^{3}$ Petroleum and Energy from Biomass Research Group (PEB), Department of Chemistry, Federal University of Sergipe, São Cristóvão, Brazil

${ }^{4}$ Instituto de Química e Biotecnologia, Universidade Federal de Alagoas, Cidade Universitária, Campus Aristóteles Calazans Simões, Avenida Lourival Melo Mota, s/n, Bairro Tabuleiro do Martins, Maceió, Brazil

${ }^{5}$ Embrapa Tabuleiros Costeiros, Bairro Jardins, Aracaju, Brazil

${ }^{6}$ Departamento de Ciências Farmacêuticas, Universidade Federal de Pernambuco, Cidade universitária, Recife, Brazil Email: anderson123soares@outlook.com, carolinecoelho7@gmail.com, mirelesantana@live.com, edson.iqb@gmail.com,
} \\ albertowj@ufs.br, adenir.teodoro@embrapa.br, *jose-guedes.sena@embrapa.br
}

How to cite this paper: de Almeida, A.S., Coelho, C.R., de Sá, M.S., Bento, E. de S., Wisniewski Junior, A., Teodoro, A.V., Xavier, H.S. and Filho, J.G. de S. (2021) Biomonitoring the Vitex gardneriana Shauer (Lamiaceae) Toxic Effects to Shed Light on Bioactive Compounds against a Major Coconut Pest Mite. American Journal of Plant Sciences, 12, 1601-1612. https://doi.org/10.4236/ajps.2021.1211111

Received: September 15, 2021 Accepted: November 2, 2021 Published: November 5, 2021

\begin{abstract}
The coconut mite, Aceria guerreronis Keifer (Acari: Eriophyidae), is a major pest of coconut plantations (Cocos nucifera L.) worldwide. Here, we conducted a bioguided phytochemical approach using toxicity and repellency bioassays of nonpolar extract and its fractions of Vitex gardneriana Schauer (Lamiaceae) leaves to this pest. Nonpolar crude extract was fractionated by column chromatography using solvents with increased polarity and binary mixtures, resulting in five semipurified groups. The biomonitoring bioassay provided active fractions and led to the isolation and characterization of the bioactive compound squalene, a biosynthetic precursor of 20-hydroxyecdysone, which plays an important role in plant defense against arthropods. The $\mathrm{LC}_{50}$ of the crude extract of $V$. gardneriana for $A$. guerreronis was estimated to be $0.185 \mathrm{mg} \cdot \mathrm{mL}^{-1}$ and $\mathrm{LC}_{80}=4.123 \mathrm{mg} \cdot \mathrm{mL}^{-1}$. Also, the extract was highly repellent to this pest for up to $24 \mathrm{~h}$. The fractions of $V$. gardneriana, and also squ-
\end{abstract}


Copyright (c) 2021 by author(s) and Scientific Research Publishing Inc. This work is licensed under the Creative Commons Attribution International License (CC BY 4.0).

http://creativecommons.org/licenses/by/4.0/ alene, caused mortality to $A$. guerreronis. The potential of $V$. gardneriana fractions/squalene as biopesticides for controlling $A$. guerreronis in coconut plantations is discussed herein.

\section{Keywords}

Bioassay, Toxicity, Phytochemistry, Terpene, Biopesticides, Biorational Control

\section{Introduction}

The Lamiaceae family constitutes taxa composed of about 236 genera and around 7000 plant species widely distributed worldwide [1] [2] [3]. Species of this family are known for their medicinal and insecticidal properties, serving as raw material for the pharmaceutical and agrochemical industry [3] [4] [5].

In this context, the Vitex genus consists of about 250 species from trees and shrubs, producing a high content of terpenes and ecdysteroids compounds, the latter being natural hormones that participate in biochemical processes in insects [6] [7] [8]. Vitex gardneriana Shauer (Lamiaceae) is restricted to the semiarid caatinga biome of Brazil's Northeast, found on the riverbanks in Paraíba, Bahia and Pernambuco states and further dispersed in the states of Sergipe and Alagoas [9] [10]. Its main constituents are terpenes, mainly sesquiterpenes, which are promising secondary compounds for the development of biopesticides [5] [10] [11].

The coconut mite Aceria guerreronis Keifer (Acari: Eriophyidae) is the most expressive pest to affect coconut plantations in tropical America, Asia, and Africa [12] [13] [14] [15]. A. guerreronis populations are found in restricted spaces under fruit bracts [16] [17]. This microhabitat makes it difficult for predatory mites to enter, making $A$. guerreronis less vulnerable to attack by predators [18]. The bracts also act as physical barriers against acaricide spraying [17] [19]. The attack of this pest leads to premature fruit drop, reduced fruit size, weight and water volume. Aesthetic skin necrosis also reduces the value of fruits intended for the fresh market [12] [19].

The control of $A$. guerreronis relies heavily on preventive spraying with acaricides, which potentially leads to several problems such as environmental and food contamination, in addition to resistance and death of natural enemies [20] [21] [22]. From this perspective, botanical insecticides may play an important role in controlling A. guerreronis without most of the harmful effects of chemical pesticides [23]. Based on this, we conducted a bioguided phytochemical study using toxicity and repellency as parameters to shed light on the bioactivity of crude extract/fractions and isolated compound from the leaves of $V$. gardneriana against the coconut mite $A$. guerreronis. 


\section{Materials and Methods}

\subsection{Living Material}

$V$. gardneriana leaves were collected in the municipality of Patos, Paraíba, Brazil. $\left(07^{\circ} 01^{\prime} 28^{\prime \prime S} ; 37^{\circ} 16^{\prime} 48^{\prime \prime} \mathrm{W}\right)$. Voucher specimens were deposited in the herbarium of the Federal University of Southwest Bahia under number 8126. This species and $A$. guerreronis were also registered in the National System for the Management of Genetic Heritage and Associated Traditional Knowledge (SisGen) under the codes A7E13BA and A5DD7EA, respectively. A. guerreronis adults were collected from fruits of a green dwarf coconut plantation located in the city of Aracaju $\left(10^{\circ} 57^{\prime} \mathrm{S} ; 37^{\circ} 03^{\prime} \mathrm{W}\right)$, Sergipe, Brazil.

\subsection{Chemical Study}

\subsubsection{Extraction and Isolation of Chemical Constituents}

The dried and crushed leaves (1400 g) were extracted four times through maceration with hexane for $48 \mathrm{~h}$ and the extracts were filtered with filter paper and evaporated to dryness at $40^{\circ} \mathrm{C}$ under reduced pressure. Column chromatography was performed on silica gel (70 - 230 and 230 - 400 mesh, Merck). The hexane extract ( $1.0 \mathrm{~g})$ was fractionated on a column of silica gel (100 g, 70 - 230 mesh) with pure solvents and binary mixtures of cyclohexane, hexane and ethyl acetate (AcOEt) in increasing polarity. The chromatographic analyses were made by Thin Layer Chromatography (TLC) on Si gel (MERCK-Germany) developed by different solvent systems and spots were visualized using a sulfuric acid-vanillin (2\%) spray reagent and then grouped into five groups: cyclohexane 100 (Fr1), cyclohexane-hexane 50:50 (Fr2), hexane 100 (Fr3), hexane-AcOEt 99.8:0.2 (Fr4) and hexane-AcOEt 99.5:0.5 (Fr5). The Fr2 group was concentrated and rechromatographed as before and eluted with cyclohexane-hexane (50:50) to generate the subfraction (6 - 14) as a colorless oil (13.0 mg).

\subsubsection{Instruments}

Nuclear magnetic resonance (NMR) and ${ }^{13} \mathrm{C}$ and ${ }^{1} \mathrm{H}$ spectra were obtained using a spectrometer (Bruker ASCEND 600). Chemical shifts were expressed in ppm (d) and coupling constants in $\mathrm{Hz}$, using a residual solvent peak or tetramethylsilane as a reference for the ${ }^{1} \mathrm{H}$ NMR spectra.

Chemical characterization of the isolated compound was analyzed by gas chromatography/mass spectrometry (GC/MS) using a TRACE 131 gas chromatograph and TSQ-9000 mass spectrometer with a TriPlus RSH autosampler (Thermo Scientific, Bremen, Germany). The separations were carried out using a $60 \mathrm{~m} \times 0.25 \mathrm{~mm} \times 0.25 \mu \mathrm{m} 5 \mathrm{MS}$ column (5\% diphenyl- and 95\% dimethylpolysiloxane) with oven programming $\left(50^{\circ} \mathrm{C}, 3 \mathrm{~min} ; 5^{\circ} \mathrm{C} \mathrm{m^{-1 }}\right.$ up to $150^{\circ} \mathrm{C}$ and $15^{\circ} \mathrm{C} \mathrm{m^{-1 }}$ up to $280^{\circ} \mathrm{C}, 15 \mathrm{~min}$ ) and carrier gas and helium flow at $1.0 \mathrm{~mL}$ $\min ^{-1}$. A volume of $0.5 \mu \mathrm{L}$ was injected with a split ratio of 1:20. The injector and interface temperature was $280^{\circ} \mathrm{C}$ and the ion source temperature was $300^{\circ} \mathrm{C}$, with an electronic energy of $70 \mathrm{eV}$ and an analysis time of $46.7 \mathrm{~min}$. The com- 
pound was identified by comparing the spectra obtained with those in the equipment database and by the retention index [24].

\subsection{Toxicity to A. guerreronis}

The crude hexane extract, the five groups of fractions obtained from the chromatographic fractionation and the isolated compound from the most active fraction were evaluated for their toxicity to $A$. guerreronis. Ten discs were made with pieces of meristematic tissue of young coconut fruits, placed in a petri dish (10 cm deep) and covered with a mixture of $5 \%$ agar, $0.3 \%$ methylparaben (Nipagim, as a fungicide) and distilled water. After solidification of the medium, ten discs of $1 \mathrm{~cm}$ in diameter were cut with a mold [25].

Concentration-mortality bioassays were performed to estimate the lethal concentration $\left(\mathrm{LC}_{50}\right)$ of the crude extract. In short, six concentrations of the extract $\left(0.025,0.5,1.0,1.5,2.0\right.$ and $\left.2.5 \mathrm{mg} \cdot \mathrm{mL}^{-1}\right)$ were prepared and the preliminary toxicity of the fractions was at the standard concentration of $1.0 \mathrm{mg} \cdot \mathrm{mL}^{-1}$, with two replicates. The samples were dissolved in acetone and sprayed on Petri dishes; spraying was performed at a pressure of $34 \mathrm{kPa}(0.34 \mathrm{bar})$ and a spray aliquot of $9.3 \mathrm{~mL}$ using a Potter tower device (Burkard, UK) [26].

After spraying, the discs were left to dry before 20 adults of $A$. guerreronis were transferred onto each disc. Ten repetitions (discs) were used for each concentration, totaling 200 mites per plate. The plates were kept in a biochemical oxygen demand (BOD) chamber at $27^{\circ} \mathrm{C} \pm 2^{\circ} \mathrm{C}$ and relative humidity of $70 \% \pm$ $10 \%$. The mortality of $A$. guerreronis was assessed after $24 \mathrm{~h}$ of exposure and the mites were considered dead when unable to move on touching gently with a brush [25].

\subsection{Repellency to A. guerreronis}

The $\mathrm{LC}_{50}$ of the hexane extracts determined in the toxicity bioassays was used in the repellency bioassay. The procedures followed the description above but only half of each disc was sprayed (half was covered with adhesive tape). The discs were left to dry for $1 \mathrm{~h}$ before one adult of $A$. guerreronis was placed on the center of each disc and its position recorded after 1 and $24 \mathrm{~h}$. Each treatment comprised three replicates and each replicate had 20 mites (60 mites per treatment) [26].

\subsection{Statistical Analysis}

The mortality data were subjected to Probit analysis to estimate lethal concentrations capable of killing $50 \%\left(\mathrm{LC}_{50}\right)$ of target organisms using the PROC PROBIT procedure in SAS (Version 5.2.38), with $p>0.05$ (SAS Institute, 2013). To assess the toxicity of the fractions obtained from fractionation, analysis of variance (ANOVA) and the Tukey test $(p<0.05)$ were performed to compare the groups with each other, and the toxicity of squalene was assessed by descriptive statistics, expressed as mean, standard error and standard deviation, using the 
BioEstat 5.0 software. The repellency of hexane extracts to A. guerreronis was determined by frequency analysis according to the chi-square test using Procfreq from the SAS software [27].

\section{Results}

\subsection{Phytochemical Investigation}

Phytochemical approach of $V$. gardneriana hexanic extract was able to identify, isolated and characterized squalene as the bioactive compounds (from the most active fraction-Fr2). Squalene, was a colorless oil (13 mg). MS: molecular ion peak at $m / z 410$.

\subsection{Toxicity to A. guerreronis}

The toxicity assay (Table 1 ) shows the estimated concentrations of the crude hexanic extract $(\mathrm{EBH})$ of $V$. gardneriana that killed $50 \%\left(\mathrm{LC}_{50}=0.185 \mathrm{mg} \cdot \mathrm{mL}^{-1}\right)$ of $A$. guerreronis $(p=0.0863)$ and that killed $80 \%\left(\mathrm{LC}_{80}=4123 \mathrm{mg} \cdot \mathrm{mL}^{-1}\right),(p=$ $0.0829)$.

The five groups of fractions (Fr1, Fr2, Fr3, Fr4 and Fr5) also were toxic to the mite in two replicates: $p<0.0001$ and $F=83.48 .06$ and $p<0.0001$ and $F=$ 10.94.71 (Table 2). The Fr2 group was the most toxic as it presented the highest mortality of mites. The Fr2 group also isolated squalene, which killed up to $44 \%$ of $A$. guerreronis at a concentration of $0.50 \mathrm{mg} \cdot \mathrm{mL}^{-1}$ (Table 3 ).

The five groups of fractions (Fr1, Fr2, Fr3, Fr4 and Fr5) also were toxic to the mite in two replicates: $p<0.0001$ and $F=83.48 .06$ and $p<0.0001$ and $F=$ 10.94.71 (Table 2). The Fr2 group was the most toxic as it presented the highest mortality of mites. The Fr2 group also isolated squalene, which killed up to $44 \%$ of $A$. guerreronis at a concentration of $0.50 \mathrm{mg} \cdot \mathrm{mL}^{-1}$ (Table 3 ).

Table 1. Lethal concentrations $\left(\mathrm{LC}_{50}\right)$ and $\left(\mathrm{LC}_{80}\right)$ of the crude extract of leaves of $V$. gardneriana to $A$. guerreronis.

\begin{tabular}{ccccc}
\hline Sample & LC50 $(95 \% \mathrm{CI})(\mathrm{mg} / \mathrm{mL})$ & $X^{2}$ & Df & $p$ \\
\hline EH & $0.18539(0.068-0.387)$ & 2.0372 & 4 & 0.0863 \\
EH & LC $80(95 \% \mathrm{CI})(\mathrm{mg} / \mathrm{ML})$ & $X^{2}$ & Df & $p$ \\
& 4.123 & 2.0620 & 4 & 0.0829 \\
\hline
\end{tabular}

Average values obtained ( $n=7$ discs with 20 adult mites each). CI $=95 \%$ confidence interval; $c^{2}=$ chi-square test $(p>0.05)$.

Table 2. Percentage toxicity of apolar fractions from $V$. gardneriana to A. guerreronis.

\begin{tabular}{lccccccc}
\hline Time 24 (h) & Dose $(1.0 \mathrm{mg} / \mathrm{mL})$ & $\operatorname{Fr}(1)$ & $\operatorname{Fr}(2)$ & $\operatorname{Fr}(3)$ & $\operatorname{Fr}(4)$ & $\operatorname{Fr}(5)$ & $(p)$ \\
\hline Replicates 1 & 52.20 & 64.40 & 56.10 & 7.20 & 30.00 & 0.0001 \\
Replicates 2 & 51.80 & 64.50 & 56.00 & 7.00 & 29.00 & 0.0001 \\
Average & 52.00 & 64.45 & 56.05 & 7.10 & 29.50 & \\
\hline
\end{tabular}

( $n=10$ discs with 20 adult mites each). 
Table 3. Squalene toxicity to $A$. guerreronis.

\begin{tabular}{ccccc}
\hline Time $(\mathrm{h})$ & $\begin{array}{c}\text { Dose } \\
\mathrm{mg} / \mathrm{mL}\end{array}$ & $\begin{array}{c}\text { Average percentage } \\
\text { mortality } \%\end{array}$ & $\begin{array}{c}\text { Standard } \\
\text { error }\end{array}$ & $\begin{array}{c}\text { Detuor } \\
\text { error }\end{array}$ \\
\hline \multirow{2}{*}{24} & 0.15 & 15.6000 & 0.0000 & 0.0000 \\
& 0.30 & 29.3500 & 0.0000 & 0.0000 \\
& 0.50 & 44.3500 & 0.0000 & 0.0000 \\
\hline
\end{tabular}

Percentage average values obtained by descriptive statistics $(n=8$ discs with twenty adult mites each).

\subsection{Repellency to A. guerreronis}

The $\mathrm{LC}_{50}$ of the hexanic extract of leaves of $V$. gardneriana repelled adults of $A$. guerreronis after 1 and $24 \mathrm{~h}$ of exposure (Figure 1).

\section{Discussion}

Previous studies have reported the isolation and identification of $V$. gardneriana chemical compounds and their biological activity. For example, the following have been obtained: ursolic and oleanolic acids; the wood acids 2a,3a,19a-trihydroxyurosan-12-en-oic, 4-carboxyphenyl 4-hydroxy-3-methoxybenzoate, 4-hydroxy-3methoxybenzoic acid and 4-hydroxybenzoic acid; from the leaves, the flavonoid 5-hydroxy-3,7,4-trimethoxyflavone; from the roots, 3,4-dihydroxybenzoic acid; and from the stem bark, the ecdysteroid 20-hydroxyecdysone and the glycosylated iridoid aucubine [10] [28]. There are reports of the chemical study of essential oils in the leaves by GC/MS, with a predominance of the sesquiterpenes cis-calamenene, 6,9-guaiadiene, karyophylene oxide and $\alpha$-cadinol [5] [11].

Chromatographic treatment of the most active fraction, Fr2, in the bioassays provided colorless oil. The ${ }^{1} \mathrm{H}$ NMR proton spectrum ( $\left.600 \mathrm{MHz}, \mathrm{CDCl}_{3}\right)$ showed the presence of five signals: $\delta \mathrm{H} 1.28$ singlet attributed to methylenic groups; $\delta \mathrm{H}$ 1.63 singlet associated with water present in the deuterated chloroform solvent; $\delta \mathrm{H} 1.70$ singlet attributed to methyl hydrogens linked to olefinic carbons; $\delta \mathrm{H}$ 1.98 - 2.07 multiplet associated with methylene hydrogens linked to olefinic carbons; and $\delta \mathrm{H} 5.10$ - 5.20 multiplet associated with the presence of olefinic hydrogens. Analysis of the ${ }^{13} \mathrm{C}$ NMR spectrum $\left(150 \mathrm{MHz}, \mathrm{CDCl}_{3}\right)$ showed the presence of 15 signals: three $\delta \mathrm{C}$ signals attributed to olefinic non-hydrogenated carbons (131.2, 134.8 and 135.1: C); three $\delta \mathrm{C}$ signals attributed to methylenic carbons next to quaternary carbons (124.3, 124.3 and 134.4: $\mathrm{CH}_{2}$ ); six $\delta \mathrm{C}$ signals attributed to methylene groups $\left(26.7,26.8,28.3,29.7,39.7\right.$ and 40.0: $\left.\mathrm{CH}_{2}\right)$; and four $\delta \mathrm{C}$ signals attributed to methyl carbons $\left(16.1,16.2,17.6\right.$ and $\left.25.1: \mathrm{CH}_{3}\right)$. These observations, associated with the presence in the mass spectrum of a molecular ion peak at $m / z 410$, and comparison of the data described in the literature [29] [30], allowed us to propose the structure of squalene, a polyunsaturated triterpene with six isoprene units, described here in $V$. gardneriana for the first time (Figure 2). Squalene has been reported to be a biochemical precursor of 


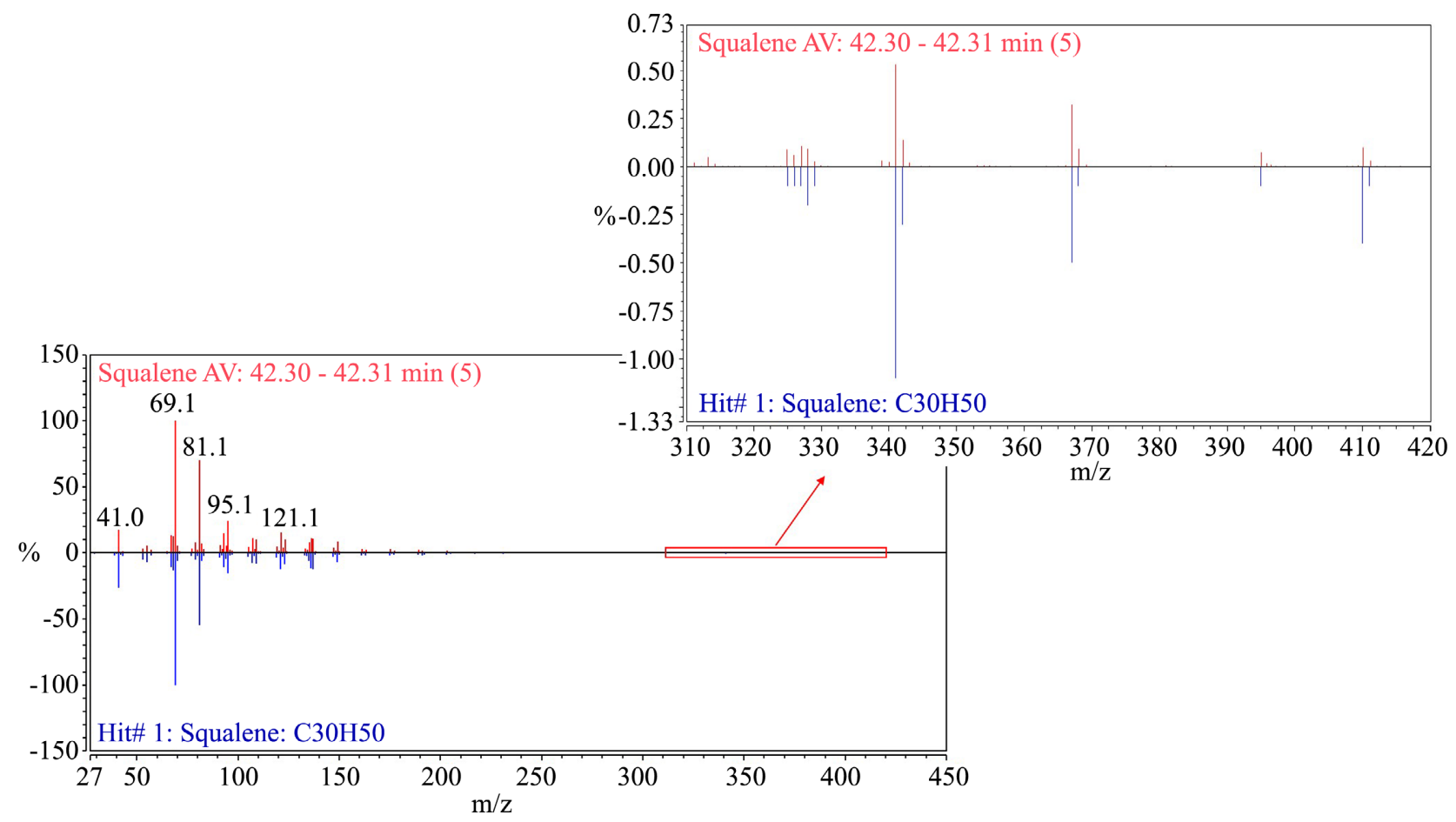

Figure 1. Expanded spectrum $m / z 317-415$.

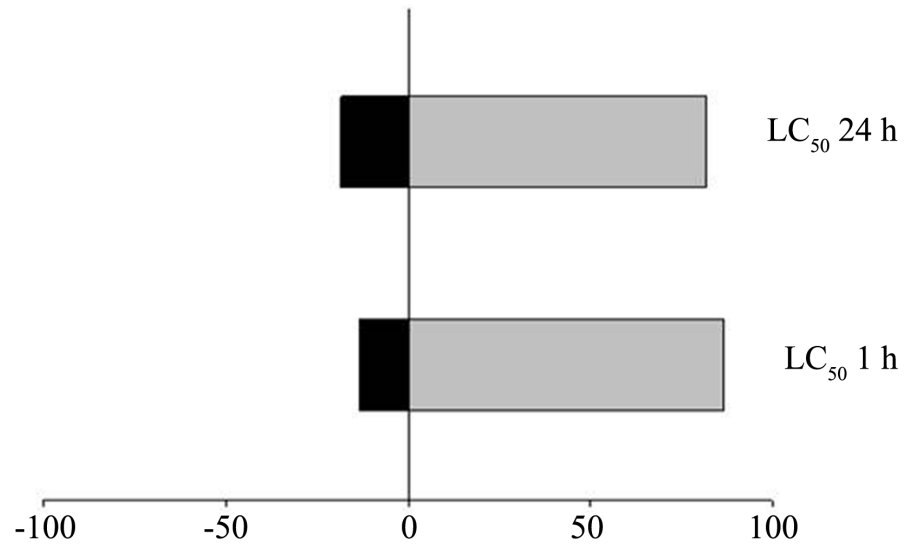

Preference of $A$. guerreronis (\%)

Figure 2. Repellency of the hexanic extract $\left(\mathrm{LC}_{50}\right)$ from the leaves of $V$. gardneriana to $A$. guerreronis.

cholesterol and other steroids. Interestingly, cholesterol is the biosynthetic precursor of ecdysone and 20-hydroxyecdysone (Figure 3), previously reported in V. gardneriana [10] [31] [32].

The results of the present study showed that the hexanic extract and fractions obtained from $V$. gardneriana were able to kill $A$. guerreronis adults. These findings suggest that extracts and fractions may have potential in the management of A. guerreronis. Similar findings have been reported in other studies showing the toxic effects of extracts from other plants of the Vitex genus against 


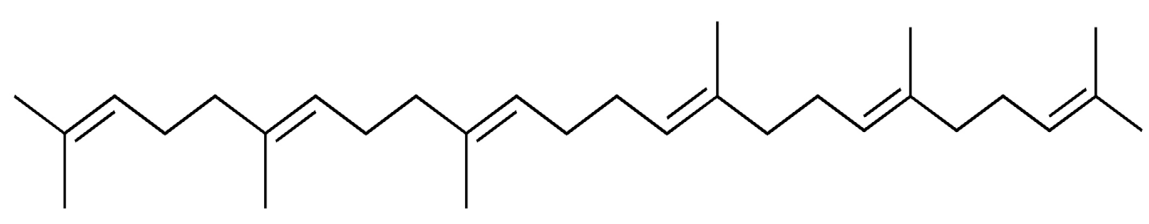

Figure 3. Chemical structure of squalene.

mites and insects [33]. For example, different extracts of the leaves of Vitex negundo L. (Lamiaceae) were active against several arthropods: the ethanolic extracts were toxic to the tick Rhipicephalus (Boophilus) microplus (Acari: Ixodidae), the hexane extract showed larvicidal action against Culex tritaeniorhynchus Giles (Culicidade) and Anopheles subpictus Grassi (Culicidade) larvae, and petroleum ether extract also had larvicidal action against $C$. tritaeniorhynchus Giles [33] [34].

Repellency bioassays indicated that the hexanic extract of $V$. gardneriana was highly repellent to $A$. guerreronis after 1 and $24 \mathrm{~h}$ of exposure. The ability to repel $A$. guerreronis suggests the irritability of these substances when the mites are in direct contact with them [35] [36]. In a parallel study, the essential oils of $V$. gardneriana, Vitex capitata Vahl and Vitex megapotamica (Spreng.) also repelled A. guerreronis [5].

Regarding the triterpene squalene isolated from the most active fraction, its toxicity towards $A$. guerreronis could be expected due to its long-chain aliphatic structure and/or the presence of alternating double bonds, as shown by other studies in which aliphatic compounds are active against cockroaches; however, the mechanism of action is uncertain [37] [38].

Interestingly, the literature reports the bioactivity of vegetable oils rich in fatty acids against $A$. guerreronis, such as crude oils from palm [25], babassu, coconut and degummed soybean, all rich in aliphatic fatty acids and showing structural similarities with squalene, which partially explains the activity against this pest mite [26]. Some enzymes are described as targets for the control of mites, such as acetylcholinesterase (AChE). Several terpenes inhibit this enzyme in the cholinergic and neuromuscular synapses of arthropods, increasing the cholinergic pathway and leading to muscle paralysis, with greater action for nonpolar lipophilic compounds that cross the lipid membranes of cells [39] [40] [41] [42].

\section{Conclusion}

The hexane crude extract from leaves of $V$. gardneriana and its bioactive fractions showed high toxicity to A. guerreronis. The bioguided study provided active fractions and led to the isolation of squalene, which proved to be bioactive against $A$. guerreronis possibly because of its aliphatic chain. Squalene is a biosynthetic precursor of 20-hydroxyecdysone, which plays an important role in plant defense against arthropods. Furthermore, the extracts/fractions of $V$. gardneriana, as well as squalene, proved to be candidates for new biopesticide formulations based on their bioactivity against $A$. guerreronis, a major pest of coconut plantations worldwide. 


\section{Acknowledgements}

The authors would like to thank the Conselho Nacional de Desenvolvimento Cientifico e Tecnológico (CNPq 405485/2016-6) and the Coordenação de Aperfeiçoamento de Pessoal de Nível Superior (CAPES) for financial support. To CLQM (Center of Multi-users Chemistry Laboratories) from Federal University of Sergipe for the facilities.

\section{Ethical Approval}

All applicable international, national, and institutional guidelines for the care and use of animals were considered in the present investigation.

\section{Conflicts of Interest}

The authors declare that they have no conflict of interest.

\section{References}

[1] Harley, R.M., Atkins, S., Budantsev, A.L., Cantino, P.D., Conn, B.J., Grayer, R., Harley, M.M., Kok, R., Krestovskaja, T., Morales, R., Paton, A.J., Ryding, O. and Upson, T. (2004) Labiatae. In: Kadereit, J.W., Ed., Flowering Plants. Dicotyledons. The Families and Genera of Vascular Plants, Vol. 7, Springer, Berlin, 167-275. https://doi.org/10.1007/978-3-642-18617-2 11

[2] Monteiro, F.K.S., Pastore, J.F.B. and Melo, J.I.M. (2018) The Flora of Paraíba State, Brazil: Subfamilies Ajugoideae and Viticoideae (Lamiaceae). Biota Neotropica, 18, e20170472. https://doi.org/10.1590/1676-0611-bn-2017-0472

[3] Alkan, M. (2020) Origanum spp. (Lamiaceae) uçucu yağlarının kimyasal kompozisyonu ve dört depolanmış ürün zararlısına karşı insektisidal potansiyeli. Türkiye Entomoloji Dergisi, 44, 149-163.

[4] Pavela, R., Benelli, G., Canale, A., Maggi, F. and Mártonfi, P. (2020) Exploring Essential Oils of Slovak Medicinal Plants for Insecticidal Activity: The Case of Thymus alternans and Teucrium montanum subsp. jailae. Food and Chemical Toxicoligy, 138, Article ID: 111203. https://doi.org/10.1016/j.fct.2020.111203

[5] de Sena-Filho, J.G., Barreto, I.C., Filho, A.O.S., Nogueira, P.C.L., Teodoro, A.V., da Silva, A.V.C., Xavier, H.S., Rabbani, A.R.C., Spakowicz, D.J. and Duringer, J.M. (2017) Volatile Metabolomic Composition of Vitex Species: Chemodiversity Insights and Acaricidal Activity. Frontiers in Plant Science, 8, 1931-1940. https://doi.org/10.3389/fpls.2017.01931

[6] Callmander, M.W., Phillipson, P.B. and Schatz, G.E. (2014) Towards a Revision of the Genus Vitex L. (Lamiaceae) in Madagascar I: A Distinctive New Species from Northeastern Madagascar. Candollea, 69, 141-147. https://doi.org/10.15553/c2014v692a5

[7] Cosmo, N.L., Gogosz, A.M., Nogueira, A.C., Bona, C. and Kuniyoshi, Y.S. (2009) Morfologia do fruto, da semente e morfo-anatomia da plântula de Vitex megapotamica (Spreng.) Moldenke (Lamiaceae). Acta Botanica Brasilica, 23, 389-397. https://doi.org/10.1590/S0102-33062009000200010

[8] Sena-Filho, J.G., Duringer, J., Maia, G.L., Tavares, J.F., Xavier, H.S., Silva, M.S., Cunha, E.V.L. and Barbosa-Filho, J.M. (2008) Ecdysteroids from Vitex Species: Distribution and Compilation of Their ${ }^{13} \mathrm{C}-\mathrm{NMR}$ Spectral Data. Chemistry \& Biodiversity, 5, 707-713. https://doi.org/10.1002/cbdv.200890067 
[9] Lima, C.T. and França, F. (2009) Flora da Bahia: Vitex Tour. ex. L. Lamiaceae. Sitientibus série Ciências Biológicas, 9, 225-244.

[10] Sá-Barreto, L.C.L., Xavier, H.S., Barbosa-Filho, J.M. and Braz-Filho, R. (2005) Ecdysteroid and Iridoid Glycoside from Vitex gardneriana Schauer (Verbenaceae). Revista Brasileira de Farmacognosia, 15, 51-54. https://doi.org/10.1590/S0102-695X2005000100011

[11] Pereira, E.J.P., Silva, H.C., Holanda, C.L., Menezes, J.E.S.A., Siqueira, S.M.C., Rodrigues, T.H.S., Fontenelle, R.O.S., Vale, J.P.C., Silva, P.T., Santiago, G.P. and Santos, H.S. (2018) Chemical Composition, Cytotoxicity and Larvicidal Activity against Aedes aegypti of Essential Oils from Vitex gardineriana Schauer. Boletín Latinoamericano y del Caribe de Plantas Medicinales y Aromáticas, 17, 302-309.

[12] Bagde, A.S., Patil, P.D. and Pashte, V.V. (2016) Screening of Coconut Genotypes against Coconut Eriophyid Mite (Aceria guerreronis Keifer.). International Journal of Bio-Resource and Stress Management, 7, 18-23.

https://doi.org/10.23910/IJBSM/2016.7.1.1486

[13] Hegade, P.B., Desai, V.S., Khaire, A.C., Narangalkar, A.L. and Haldankar, P.M. (2017) Survey of Coconut Eriophyid Mite Aceria guerreronis (Keifer) (Acarina: Eriophyidae) in Ratnagiri District of Konkan Region of Maharashtra. Environment and Ecology, 35, 2396-2402.

[14] Návia, D., Gondim, M.G.C., Aratchige, N.S. and Moraes, G.J. (2013) A Review of the Status of the Coconut Mite, Aceria guerreronis (Acari: Eriophyidae), a Major Tropical Mite Pest. Experimental and Applied Acarology, 59, 67-94. https://doi.org/10.1007/s10493-012-9634-x

[15] Nkansah-Poku, J., Quaicoe, R.N. and Sam, G. (2015) Incidence of Coconut Mite, Eriophyes guerreronis Keifer (ACARI: Eriophyidae) Infestation on Coconut in the Western and Central Regions of Ghana. Journal of Ghana Science Association, 16, 36-44.

[16] Lima, D.B., Oliveira, H.K.V., Melo, J.W.S., Gondim, M.G.C., Sabelis, M., Pallini, A. and Janssen, A. (2017) Predator Performance is Impaired by the Presence of a Second Prey Species. Bulletin of Entomological Research, 107, 313-321.

[17] Silva, V.F., França, G.V., Melo, J.W.S., Guedes, R.N.C. and Gondim, M.G.C. (2017) Targeting Hidden Pests: Acaricides against the Coconut Mite Aceria guerreronis. Journal of Pest Science, 90, 207-215. https://doi.org/10.1007/s10340-016-0776-1

[18] Lima, D.B., Melo, J.W.S., Gondim, M.G.C. and Moraes, G.J. (2012) Limitations of Neoseiulus baraki and Proctolaelaps bickleyi as Control Agents of Aceria guerreronis. Experimental and Applied Acarology, 56, 233-246.

https://doi.org/10.1007/s10493-012-9515-3

[19] Rezende, D., Melo, J.W.S., Oliveira, J.E.M. and Gondim, M.G.C. (2016) Estimated Crop Loss Due to Coconut Mite and Financial Analysis of Controlling the Pest Using the Acaricide Abamectin. Experimental and Applied Acarology, 69, 297-310. https://doi.org/10.1007/s10493-016-0039-0

[20] Guedes, R.N., Smagghe, G., Stark, J.D. and Desneux, N. (2016) Pesticide-Induced Stress in Arthropod Pests for Optimized Integrated Pest Management Programs. Annual Review of Entomology, 61, 43-62. https://doi.org/10.1146/annurev-ento-010715-023646

[21] Monteiro, V.B., Lima, M.D.B., Gondim, M.G.C. and Siqueira, H.A.A. (2012) Residual Bioassay to Assess the Toxicity of Acaricides against Aceria guerreronis (Acari: Eriophyidae) under Laboratory Conditions. Journal of Economic Entomology, 105, 1419-1425. https://doi.org/10.1603/EC11400 
[22] Roubos, C.R., Rodriguez-Saona, C., Holdcraft, R., Mason, K.S. and Isaacs, R. (2014) Relative Toxicity and Residual Activity of Insecticides Used in Blueberry Pest Management: Mortality of Natural Enemies. Journal of Economic Entomology, 107, 277-285. https://doi.org/10.1603/EC13191

[23] Isman, M.B. and Grieneisen, M.L. (2014) Botanical Insecticide Research: Many Publications, Limited Useful Data. Trends in Plant Science, 19, 140-145. https://doi.org/10.1016/j.tplants.2013.11.005

[24] Adams, R.P., et al. (2007) Identification of Essential Oil Components by Gas Chromatography/Mass Spectrometry. 4th Edition, Allured Publishing Corporation, Carol Stream.

[25] Freitas, G.S., Sena-Filho, J.G., Saraiva, W.V.A., Vieira, I.G., Oliveira, E.E. and Teodoro, A.V. (2019) Acaricidal Activity of Palm Oil on Aceria guerreronis (Acari: Eriophyidae) and a Nontarget Predator. Journal of Entomological Science, 54, 172-180. https://doi.org/10.18474/JES18-67

[26] Oliveira, N.N.F.C., Galvão, A.S., AmaraL, A., Santos, A.W.O., Sena-Filho, J.G., Oliveira, E.E. and Teodoro, A.V. (2017) Toxicity of Vegetable Oils to the Coconut Mite Aceria guerreronis and Selectivity against the Predator Neoseiulus baraki. Experimental and Applied Acarology, 72, 23-34.

https://doi.org/10.1007/s10493-017-0134-x

[27] SAS Institute (2013) SAS/ STAT User's Guide. Version 8.02. SAS Institute Inc., Cary, NC.

[28] Vale, J.P.C., Gonçalves, F.B., Silva, P.T., Bandeira, P.N., Teixeira, E.H., Vasconcelos, M.A., Sampaio, A.H., Saker-Sampaio, S., Braz-Filho, R. and Santos, H.S. (2017) Isolation and Antioxidant Activity of Chemical Constituents from Vitex gardneriana Schauer. Journal of Pharmacognosy and Phytochemistry, 6, 1806-1811.

[29] Cursino, L.M.C., Mesquita, A.S.S., Mesquita, D.W.O., Fernandes, C.C., Junior, O.L.P., Amaral, I.L. and Nunez, C.V. (2009) Triterpenos das folhas de Minquartia guianensis Aubl. (Olacaceae). Acta Amazonica, 39,181-185. https://doi.org/10.1590/S0044-59672009000100018

[30] Miranda, M,L.D., Garcez, F.R. and Garcez, W.S. (2015) Triterpenos e outros constituintes dos frutos de Enterolobium contortisiliquum (Vell.) Morong (Fabaceae). Revista Virtual de Química, 7, 2597-2605. https://doi.org/10.5935/1984-6835.20150154

[31] Reddy, L.H. and Couvreur, P. (2009) Squalene: A Natural Triterpene for Use in Disease Management and Therapy. Advanced Drug Delivery Reviews, 61, 1412-1426. https://doi.org/10.1016/j.addr.2009.09.005

[32] Thiem, B., Nikowska, M., Malinski, M.P., Kruszka, D., Napierala, M. and Florek, M. (2017) Ecdysteroids: Production in Plant in Vitro Cultures. Phytochemistry Reviews, 16, 603-622. https://doi.org/10.1007/s11101-016-9483-Z

[33] Singh, N.K., Vemu, J.B., Nandi, A., Singh, H., Kumar, R. and Dumka, V.K. (2014) Acaricidal Activity of Cymbopogon winterianus, Vitex negundo and Withania somnifera against Synthetic Pyrethroid Resistant Rhipicephalus (Boophilus) microplus. Parasitology Research, 113, 341-350.

https://doi.org/10.1007/s00436-013-3660-4

[34] Kamaraj, C., Bagavan, A., Rahuman, A.A., Zahir, A.A., Elango, G. and Pandyan, G. (2009) Larvicidal Potential of Medicinal Plant Extracts against Anopheles Subpictus Grassi and Culex tritaeniorhynchus Giles (Diptera: Culicidae). Parasitology Research, 104, Article No. 1163. https://doi.org/10.1007/s00436-008-1306-8

[35] Cordeiro, E.M.G., Corrêa, A.S., Vezon, M. and Guedes, R.N.C. (2010) Insecticide 
Survival and Behavioral Avoidance in the Lacewings Chrysoperla externa and Ceraeochrysa cubana. Chemosphere, 81, 1352-1357.

https://doi.org/10.1016/j.chemosphere.2010.08.021

[36] Lockwood, J.A., Sparks, T.C. and Story, R.N. (1984) Evolution of Insect Resistance to Insecticides: A Reevaluation of the Roles of Physiology and Behavior. Bulletin of the Entomological Society of America, 30, 41-51.

https://doi.org/10.1093/besa/30.4.41

[37] Baldwin, R.W., Koehler, P.G. and Pereira, R.M. (2008) Toxicity of Fatty Acid Salts to German and American Cockroaches. Journal of Economic Entomology, 101, 1384-1388. https://doi.org/10.1093/jee/101.4.1384

[38] Parry, W.H. and Rose, R. (1983) The Role of Fatty Acids and Soaps in Aphid Control on Conifers. Zeitschrift für Angewandte Entomologie, 96, 16-23.

https://doi.org/10.1111/j.1439-0418.1983.tb03634.x

[39] Loizzo, M.R., Tudins, R., Menichini, F. and Menichini, F. (2008) Natural Products and Their Derivatives as Cholinesterase Inhibitors in the Treatment of Neurodegenerative Disorders: An Update. Current Medicinal Chemistry, 15, 1209-1228. https://doi.org/10.2174/092986708784310422

[40] Loizzo, M.R., Tudins, R., Conforti, F., Menichini, F., Bonesi, M., Nadjafi, F., Frega, N.G. and Menichini, F. (2010) Salvia leriifolia Benth (Lamiaceae) Extract Demonstrates in Vitro Antioxidant Properties and Cholinesterase Inhibitory Activity. $\mathrm{Nu}$ trition Research, 30, 823-830. https://doi.org/10.1016/j.nutres.2010.09.016

[41] Ribeiro, V.L.S., Santos, J.C., Martins, J.R., Schripsema, J., Siqueira, I.R., Poser, G.L.V. and Apel, M.A. (2011) Acaricidal Properties of the Essential Oil and Precocene II Obtained from Calea serrata (Asteraceae) on the Cattle Tick Rhipicephalus (Boophilus) microplus (Acari: Ixodidae). Veterinary Parasitology, 179, 195-198. https://doi.org/10.1016/j.vetpar.2011.02.006

[42] Ribeiro, V.L.S., Vazella, C., Moysés, F.S., Santos, J.C., Martins, J.R.S., Poser, G.L.V. and Siqueira, I.R. (2012) Effect of Calea serrata Less. n-Hexane Extract on Acetylcholinesterase of Larvae Ticks and Brain Wistar Rats. Veterinary Parasitology, 189, 322-326. https://doi.org/10.1016/j.vetpar.2012.04.033 